\title{
Motives For Employee Profit Sharing Schemes In The U.S., U.K. And Canada
}

Alireza Daneshfar, University of New Haven, USA

Farhad Simyar, Chicago State University, USA

Michael Rolleri, University of New Haven, USA

Robert Wnek, University of New Haven, USA

\begin{abstract}
This paper discusses different motives for profit sharing adoption in the U.S., Canada and the $U . K$., and analyzes employment-based factors that could contribute to these differences. Motives for profit sharing are classified into two groups: motivational and non-motivational. A theoretical model is presented that suggests a firm's ability to use profit sharing for non-motivational purposes is limited by the status of domestic employment-related factors. The analytical review indicates that the non-motivational use of profit sharing is limited by the status of employmentrelated factors in each of the studied countries. However, the non-motivational use of profit sharing is probable if higher labor productivity is expected through other means. Implication of the results is discussed for future studies in this area.
\end{abstract}

\section{INTRODUCTION}

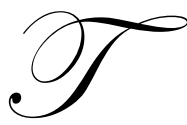

he use of employee profit sharing plans as an employee compensation scheme has increased significantly in the workplace. In the U.S., for example, about one in every four companies offers some type of profit sharing plan. Also, several studies have found profit sharing as an effective compensation scheme (e.g. Kruse, 1993; Cheadle, 1989). Employee profit sharing has been gaining popularity as a means of employee compensation because it links employee payments to the company's financial performance. Profit sharing payments are affected by changes in the firm's earnings and affect both the income and cash flow statements. Additionally, the decision to select profit sharing among available compensation schemes requires a careful analysis of the company's earnings potential and affect on income. However, accounting literature, including accounting textbooks, have little discussion of the effect that employee profit sharing has on the accounting system and financial statements. The need for such a discussion is even more necessary for international accounting professionals and upper management since multinational companies are faced with different social and legal standards that may affect employees' opinions about profit sharing plans and their effectiveness on productivity. This paper brings this gap closer by discussing the motives for profit sharing adoption in North America (U.S. and Canada) and the U.K. and the reasons for the differences among them. These countries were selected since they are among the largest economies in the world and where many multinational firms have operations. Further, these countries are similar socially and culturally, such similarities minimizing the affect of various non-economical factors on the selection process.

This paper should help researchers and professional accountants considering the effect of factors that affect adoption and execution of profit sharing schemes in multinational companies, especially in the United States, Canada and the U.K. This is an important issue since different motives for profit sharing, and the sources of those differences, could affect the outcome of financial analysis.

This paper continues as follows: The next section delineates the different motives involved in decisions to adopt profit sharing schemes. Section three presents employment-based sources of the differences. Section four offers a summary and discussion. 


\section{COMPARISON OF MOTIVES}

The motives for the adoption of profit sharing schemes as documented in the literature could be classified as follows: labor productivity, monitoring costs, wage flexibility, plan administrative costs, union status and management philosophy. These motives are discussed as follows.

\section{Labor Productivity}

Researchers generally agree that firms offer profit sharing in order to promote higher employee productivity, which is achieved through higher employee motivation and involvement. This can be achieved by aligning employees' goals with those of the firm. When a firm's profits are shared between owners and employees, employees have a higher stake in the success of the firm. Research generally supports this motive for profit sharing adoption across the examined countries. In the U.S., for example, Kruse (1996) found that there is a positive relationship between the adoption of profit sharing and the existence of job enrichment programs, where enrichment programs were offered to encourage higher employee input and involvement. In the U.K., profit sharing was used to improve employee involvement in decision-making, measured by the simultaneous existence of profit sharing schemes and workers' councils (Estrin and Wilson, 1989). In Canada, Wagar and Long (1995) found a relationship between a higher number of self-directed work teams and the existence of profit sharing, a result that reflects the fact that self-directed work requires greater motivation and involvement.

\section{Monitoring Costs}

According to agency theory, a monitoring system is required to prevent employees from pursuing self-serving actions. However, monitoring systems can be costly and employees' actions are often complex and not fully observable. Thus, indirect monitoring systems such as variable compensation schemes can be used for this purpose. In this context, profit sharing can be used to complement direct monitoring systems and reduce supervisory costs because employees will have an incentive to observe the actions of their peers. Accordingly, less supervisory costs are required when profit sharing is in place. Each employee's individual actions have an impact on the profitability of the entity.

While the research results support this motive in the U.S. and Canada, contrary evidence has been reported in the U.K. In the U.S., a positive relationship was found between the existence of profit sharing and the productivity of engineering personnel (Gregg and Machin, 1988), given that the cost of supervision is higher in professional organizations and profit sharing was used to mitigate it. In Canada, two different studies found that firms with profit sharing were less hierarchical than those without it (Long, 1994; Wagar and Long, 1995). Specifically, it was found that firms with profit sharing had 31\% fewer supervisors and managers (Long, 1994). However, the supervisor-employee ratio was found to be higher in U.K. firms with profit sharing plans (Gregg and Machin, 1988), indicating that profit sharing was not used for the purpose of lower monitoring costs.

\section{Wage Flexibility}

It has been argued that a firm may use profit sharing for the purpose of wage flexibility, to avoid costly wage decreases at times of low profitability. According to this argument, the marginal cost of labor is lower when profit sharing is adopted because part of labor cost becomes variable and changes with increases and decreases in the firm's profit. Therefore, firms pay employees less when profit is lower and pay more when profit is higher. According to this argument, firms with unstable financial circumstances and lower financial prospects are more likely to adopt profit sharing because they are in greater need of avoiding fixed wage commitments to employees.

Studies of the wage flexibility motive have reached contrary conclusions across the examined countries. In the U.S., Kruse (1996) reported support for this argument since it was found that the existence of profit sharing was associated with high profit variability. In the UK, it was found that financially stable firms mainly offered profit sharing, suggesting that profit sharing was not used to increase wage flexibility (Estrin and Wilson, 1989). In Canada, Wagar and Long (1995) found no relationship between the existence of profit sharing and environmental turbulence. 
In addition to the motives for profit sharing adoption, several studies found that some contextual factors also affect profit sharing adoption. The following section reviews the effects of these factors.

\section{Plan Administrative Costs}

There is a theoretical debate concerning the relationship between plan administrative costs (resented by the firm size) and the adoption of profit sharing plans. Some researchers argue that profit sharing is more effective in smaller firms as the link between individual employees and a firm's performance is more direct and the opportunities for "free riders" are lower. Thus, smaller firms are more likely to adopt profit sharing than larger firms. On the other hand, some other researchers believe that the administration costs of profit sharing are considerable and smaller firms are unable to afford them. Thus, larger firms are more likely to adopt profit sharing plans.

The research results for the plan administrative costs presented by firm size are mixed. In the U.S., the relationship between the existence of profit sharing and firm size was reported positive by Fitzroy and Kraft (1987) and no association was reported by Cheadle (1989). In the U.K, Gregg and Machin (1988) and Poole (1989) found a positive relationship, whereas Estrin and Wilson (1989) reported a negative one. In Canada, Wagar and Long (1995) and Long (1989) found no relationship between firm size and the adoption of profit sharing.

\section{Union Status}

Researchers have argued that union status negatively influences the adoption of profit sharing plans as union leaders oppose profit sharing. They do so for two main reasons: First, they worry that profit sharing may undermine their members' commitment to the union and increase their commitment to the firm. Secondly, unions generally favor fixed wage increases instead of variable compensation such as profit sharing.

Research findings are mixed on the effect of unions across the examined countries. In the U.S., Kruse (1991) found no relationship between the adoption of profit sharing and union status, while Kruse (1993) reported a positive relationship. On the other hand, Cheadle (1989), Kim (1993) and Cooke (1994) reported a negative relationship. In the U.K., research results are mixed. Poole (1989) has reported a negative relationship, Gregg and Machin (1988) have reported a positive relationship, and Estrin and Wilson (1989) have reported no relationship. In Canada, researchers have generally found a negative relationship between the adoption of profit sharing and unionization (Long, 1989; Jones and Pliskin, 1991; Betcherman et al., 1994; Wagar and Long, 1995), with the exception of Long (1997), who found no relationship.

\section{Management Philosophy}

Scholars argue that a firm's management philosophy (the management's school of thought) may affect the adoption of profit sharing. Three schools have been identified: classical, human relations and human resources (Miles, 1975). According to the classical school, people are motivated only by economic self-interest. Therefore, management that follows this thinking will impose rigid control of employees' actions. The human relations school argues that people are motivated by social rewards that the organization can offer and it suggests a control-oriented approach. However, controls are exercised through the development of group norms rather than through constant supervisory surveillance. According to the third school of thought, people can be self-motivated if their work is challenging and interesting. This school suggests providing employees with sufficient autonomy if employee's goals are integrated with that of the organization. Only the third school of thought is expected to promote profit sharing plans.

There is no research evidence available at this time that examines the effect of different schools of thought on profit sharing adoption in the U.S. and U.K. However, in Canada, Long (1997) found a positive association between the adoption of profit sharing and the human resources school of thought, and a negative relationship between profit sharing adoption and the classical school. 
Table 1 presents a summary of the motives for profit sharing adoption across the examined countries. The comparison indicates the only motive that is consistent across the examined countries is higher employee motivation and that the other motives are inconsistent.

Table 1: Comparison of Motives for Profit Sharing Adoption in U.S., Canada and U.K.

\begin{tabular}{|l|l|l|l|}
\hline \multicolumn{1}{|c|}{ Profit Sharing Plan Determinants } & \multicolumn{1}{c|}{ US } & \multicolumn{1}{c|}{ Canada } & \multicolumn{1}{c|}{ UK } \\
\hline Employee Productivity & Positive Relation & Positive Relation & Positive Relation \\
\hline Wage flexibility & Positive Relation & No Relation & Negative Relation \\
\hline Lower monitoring costs & Positive Relation & Positive Relation & No Relation \\
\hline Size & Mixed Relation & No Relation & Mixed Relation \\
\hline Union membership & Mixed Relation & Negative Relation & Mixed Relation \\
\hline Managerial philosophy & No Evidence & Positive Relation & No Evidence \\
\hline
\end{tabular}

\section{SOURCES OF DIFFERENT MOTIVES FOR PROFIT SHARING}

\section{When will a Firm Offer Employee Profit Sharing?}

Profit sharing is an economic agreement between a firm and its employees to share financial outcomes under certain conditions. According to agency theory, employees have less incentive to increase their inputs when they are given a fixed payment (Watts and Zimmerman, 1986). On the other hand, a flexible wage system can increase employee participation and productivity as the amount of compensation is linked to the firm's performance. Among different options, profit sharing has been the most common and oldest type of compensation scheme under which employees receive a share of a firm's income (Baker et. al., 1988; Kren and Kerr, 1993; Jensen and Murphy, 1990). Under profit sharing, employees become stakeholders who receive a share of the firm's earnings in a way similar to that of investors and executives. Accordingly, earnings are distributed among investors, executives and employees as indicated by the equation [1] below:

$I_{N C}=a_{I N} I N C_{t}+a_{E X} I N C_{t}+a_{E M} I N C_{t}$

Where $\mathrm{INC}_{\mathrm{t}}$ presents income before the parties' charges for their regular services such as fixed salaries, $\mathrm{a}$ presents the distribution coefficient for each party in the model, which varies from zero to one (zero indicates zero share and one indicates total share of income), IN and EX and EM present investors, executives and employees respectively and ${ }_{t}$ is an indicator of time.

The three parties, owners, executives and employees, are included in the model for several reasons. First, the concept of "firm" is widely accepted in the today's economy and executives rather than owners mainly manage firms. Second, it is assumed that profit sharing with executives could exist regardless of whether employee profit sharing exists or not. This assumption is reasonable as many firms offer a form of executive profit sharing independent from employee profit sharing (Tosi and Gomez-Mejia, 1989). By offering employee profit sharing, the firm's net income is distributed among investors, executives and employees. Employees can expect higher compensation if the firm's earnings $\left(\mathrm{INC}_{\mathrm{t}}\right)$ increase. Similarly, their compensation will be lower if the firm's earnings decrease. The percentage of distribution will depend on the compensation arrangement and is negatively related to the other two parties' compensation in the model, as presented by equation 2 :

$a_{E M}=-a_{I N}-a_{E X}+1$

Equation 2 indicates that investors and executives will give up a portion of their share to employees when profit sharing is in place. In equilibrium, they are willing to give up a percentage of income to employees only if the expected benefit from profit sharing is higher than the income relinquished. However, the expected benefits are related to the motivational use of profit sharing, non-motivational use or both. Although a firm may be willing to use profit sharing for both motivational and non-motivational purposes, the use of profit sharing is limited by the status of domestic employment-related factors. For example, when labor productivity is high in a country, firms may assign a lower weight to the use of profit sharing for motivational goals and assign a higher weight to non- 
motivational goals. Therefore, the motive for profit sharing adoption can be affected by the status of domestic employment-related factors and the motives, as indicated by equation [1] and [2], will be different in different countries. Figure 1 demonstrates this relationship and the effect of the components of employment-related factors on the motivational and non-motivational uses of profit sharing.

Figure 1: The Effect of Employment-Related Factors on Motives for Profit Sharing Adoption

\begin{tabular}{|c|c|c|}
\hline $\begin{array}{l}\text { Motives and Contextual Factors: } \\
\text { - Employee Productivity } \\
\text { - Wage Flexibility } \\
\text { - Lower Monitoring Costs } \\
\text { - Firm Size } \\
\text { - Union Status } \\
\text { - Management Philosophy }\end{array}$ & & $\begin{array}{l}\text { Profit Sharing Adoption For } \\
\text { Motivational and Non- } \\
\text { motivational Purposes }\end{array}$ \\
\hline & $\begin{array}{l}\text { Employment-related Factors: } \\
\text { - } \text { National Employee } \\
\text { Productivity and costs } \\
\text { - } \text { Availability of qualified } \\
\text { employees } \\
\text { - } \text { Subsidization of employee Cost } \\
\text { - } \text { Domestic Union Differences }\end{array}$ & \\
\hline
\end{tabular}

\section{What are Employment-related Factors?}

National Labor Productivity and Labor Costs

The status of labor productivity and labor costs may affect the expectation of profit sharing benefits and consequently motives for profit sharing. When labor productivity decreases, more labor is required to perform the same job, which results in higher total labor costs and consequently lower net income. The same affect exists for labor costs. When unit labor cost increases without any change in labor output, total expenses will increase and the company net income will shrink, all other factors being equal. Low labor productivity and higher labor unit costs require more innovative employee compensation policies to enhance higher labor participation. High labor unit costs may also limit future fixed wage increases and encourage variable compensation polices such as profit sharing to attempt to increase productivity and profits. Changes in labor productivity and costs have been considerably different in the U.S., U.K. and Canada. Sparks and Greiner (1997) have reported that the percentage of positive change in the U.S. labor productivity from 1994 to 1995 was 3.4, while that of U.K. was -.8 and that of Canada was 1. More recent studies also found that productivity growth in the U.S. was significantly higher than productivity in Canada and U.K. (Crawford, 2002). The U.S. also had a lower percentage of increase in labor unit cost. The percentage of change in labor unit costs for the U.S. in 1995 was found to be .3, for the U.K., 1.7 and for Canada, .5 (Sparks and Greiner, 1997). The more updated statistics indicated that the percentage of change in hourly compensation costs from 1998 to 1999 for U.S. was 2.9 percent and for the U.K. was 3.3 percent (Hansen, 2000). Cobet and Wilson (2002) also found that the change in manufacturing labor costs in the period of 1990 to 2000 was -.2 for the U.S., -.8 for Canada and 2.1 for U.K., indicating that work environment was different in these countries, leading to a different wage structures.

The differences in labor productivity and costs in the examined countries may have influenced the motive of profit sharing adoption for wage flexibility and lowering monitoring costs. The statistics show that firms in the U.K. are in a disadvantageous position in terms of increases in labor costs and lower profitability. Thus, firms in this country tend to use profit sharing mainly for the purpose of increasing labor inputs instead of for the purpose of 
wage flexibility and lowering monitoring costs. Also, this conclusion is supported by statistics on the status of labor productivity and costs in Canada and the U.S. In Canada, labor productivity is higher than in the U.K. and labor costs are lower. Thus, I observe some departure from the use of profit sharing for merely higher labor incentives toward some other purposes (in this case, lowering monitoring costs). For the U.S., where I see strong evidence of higher labor productivity and lower labor costs, I observe even more departure from the use of profit sharing for higher labor incentives toward other purposes (in this case, wage flexibility and lower supervisory costs).

\section{Availability of Qualified Employees}

Studies have also found that the examined countries are different in terms of the availability of qualified employees. Blessing and Kim (1998) found that U.K. companies had more difficulty in recruiting employees with the right qualifications and experience. A 1999 McKinsey report also shows that the U.K. has been lagging behind both the U.S. and Canada in terms of the skill level of its workforce (Whitmore, 1999). On the other hand, Sorrentino and Moy (2002) found that the U.S. has changed from being a high unemployment nation to being a low unemployment nation in the period between 1960 to 2000, while the pattern has been reversed in the U.K.; during the same period, the U.K. has changed from being a low unemployment to being a high unemployment nation. The pattern has been the same in Canada for being a not too high and not too low unemployment nation. Sorrentino and Moy (2002) also found that in the U.S. and Canada strong job creation and employment growth greatly surpassed the population growth during the period of 1960 to 2000, while the U.K. had slower employment increases. Such changes require different policies for employment and compensation, and consequently imply differences in the tendency toward profit sharing adoption. The statistics show that British firms, and to some extent Canadian firms, are facing the challenge of a high unemployment rate coupled with lower labor productivity. A higher unemployment rate does not necessarily mean a higher availability of qualified employees. In fact, a high unemployment rate may indicate the existence of a workforce without the right qualifications. Accordingly, firms in the U.K. may use profit sharing mainly as a means of attracting and retaining employees because of difficulty in recruiting qualified employees. On the other hand, U.S. firms have had fewer problems in finding qualified employees, and consequently were able to use profit sharing for non-motivational purposes such as wage flexibility and lowering monitoring costs. This conclusion is in agreement with the evidence that profit sharing was not used for wage flexibility or lower monitoring costs purposes in the U.K., but it was used for these purposes in the U.S.

\section{Subsidization of Employee Cost Differences}

Another component of domestic workplace economics is the subsidization of labor costs, such as healthcare expenses, social benefits and governmental senior assistance programs.. This subsidization is affected by a country's domestic social structure and workplace circumstances. The subsidization of labor costs has been found to differ significantly among the studied countries. For example, in Canada employment benefit costs are lower than those in the U.S. due to the government's subsidization of healthcare coverage (Spencer, 1994). Also, Hogan and Kerstein (1999) found that both Canada and the U.K. have larger government social security and retirement benefits than US has. Thus, the amounts and number of benefits that U.S. firms offer to their employees are higher than those of Canadian and U.K. firms, causing U.S. firms to be reluctant to offer additional compensation and benefits. The existence of labor cost subsidization promotes the discussion of the fairness of the wage system and wealth distribution in a country and encourages profit sharing as a means of wealth distribution rather than as a managerial strategy. Majerus (1984) found that this objective was sought by firms that adopted profit sharing. This phenomenon may explain why profit sharing was not used to increase wage flexibility in Canada and the U.K. and may also explain the results of studies regarding the affect of firms' size in Canada since all firms regardless of their size enjoy government assistance.

\section{Domestic Union Differences}

The influence of unions on profit sharing adoption was found to differ substantially among the examined countries due to differences in union structure in those countries. Kaufman and Taras (1999) found that in the late 1990s, only slightly more than ten percent of private sector employees in the U.S. were unionized, while in the Canadian private sector, figures were just under twenty two percent. Another example of differences between union coverage in the U.S. and Canada is that of the professional worker. Baker and Fortin (1998) found that health care 
workers (nursing and therapy occupations) had union coverage of more than $85 \%$ in Canada. In the U.S., union coverage rates in these occupations are less than 20 percent. Boyer et al., (2001) found that unionism has shrunk in the U.S. and U.K., and that nonunion employees now represent more than $80 \%$ of the work force in the U.S. and nearly two thirds of that in the U.K. Bassett (1988) found that nonunion employment is much more common in the U.S. than in the U.K.

Increases in nonunion labor organizations are also found to be different in the examined countries. Nonunion organizations such as joint industrial councils, peer-review discipline resolution panels and nonunion professional employees' associations work in a similar manner to that of unions (Lawler 1992; Levine, 1995). However, nonunion organizations are treated differently in the examined countries. In the U.S., the Wagner Act contains statutory restrictions that effectively ban most forms of nonunion employee representation (Estreicher, 1994; LeRoy, 1996). The act forbids any form of labor organization - including committees, teams and councilsthat is of a representational nature; is created, financed, or operated by an employer; and involves bilateral discussions about the terms and conditions of employment. However, nonunion employee representation is legal in Canada because the Canadian legislature recognizes many different types of labor organizations, including nonunion organizations (Kaufman and Taras, 1999).

This evidence implies that union and labor organization structures are substantially different in the examined countries and this may have different effects on compensation strategies, including profit sharing. This evidence may explain why prior research has found more consistent research results for the union effect in Canada, but less consistent results in the U.S. and U.K.

\section{SUMMARY AND DISCUSSION}

This paper reviewed different motives for profit sharing adoption in North America and the U.K. Table 1 showed that the motives are considerably different although these countries share many social and cultural similarities. The paper also presented a theoretical framework for adopting a profit sharing plan and discussed several employment-related factors that could contribute to the differences of motives for profit sharing. Researchers and professional accountants could benefit from this paper by addressing the effect of employment-related factors on the examination of motives for profit sharing adoption and their affect on financial analysis. Future studies might also extend this study in several aspects. First, they might examine whether the conclusions arrived at based on the countries examined here could be extended to other countries. Such a study would help assess the generalizability of the argument presented in this paper. Secondly, studies might examine whether there are considerations other than employment-related factors that could be used to explain the inconsistency of motives for profit sharing adoption across countries. Thirdly, the arguments presented in this paper could directly or indirectly benefit from an empirical study in this area. The current study also has some limitations. It discusses the cases of the U.S., Canada and U.K. only. In addition, it does not discuss the effects of factors such as tax regulations, as they are beyond the scope of this paper. Future studies might gainfully expand on this paper by examining those factors that could not be discussed here.

\section{REFERENCES}

1. Baker, M. and N. M. Fortin. 1998. Women's Wage in Women's Work: A US / Canada Comparison of The Roles of The Unions And "Public Goods" Sector Jobs. Topics in Labor Economics, 89: 198-203.

2. Baker, G. P.; M.C. Jensen and K. J. Murphy. 1988. Compensation and Incentives: Practice Versus Theory. Journal of Finance, 33: 593-616.

3. $\quad$ Bassett, P. 1988. Non-Unionism's Growing Ranks. Personal Management, 20: 44-47.

4. Betcherman, G., K. McMullen, N. Leckie, and C. Caron. 1994. The Canadian Workplace in Transition. The Worklife Report, 9: 1-2.

5. Blessing, T. W. and I. Kim. 1998. In Search of Greener Pastures; Should You Change Jobs - or 'Customize' Your Current Job to Fit You Better? Chemical Engineering New York, 105: 165-167.

6. Boyer, R. G., D. Marsden, P. Teague and E. M. Garza. 2001. Review Symposium: Converging Divergences: Worldwide Changes in Employment Systems, By Henry C. Katz And Owen Darbishire / Commentaries. Industrial And Labor Relation Review, 54: 681-716. 
7. Carstensen, V., K. Gerlach and O. Hubler. 1992. Profit Sharing in German Firms: Institutional Framework, Participation, And Macroeconomic Effects. Institutional Framework And Labor Market Performance: Hannover Ybuversity, Berlin.

8. Cheadle A. 1989. Explaining Patterns of Profit Sharing Activity. Industrial Relations, 28: $387-400$.

9. Cobet, A. E. and G. A. Wilson. 2002. Comparing 50 Years of Labor Productivity in US And Foreign Manufacturing. Monthly Labor Review, 125: 51-65.

10. Cooke, W. N. 1994. Employee Participation Programs, Group-Based Incentives, And Company Performance: A Union-NonunionComparison. Industrial And Labor Relations Review, 47: 594-609.

11. Crawford, A. 2002. Trends in Productivity Growth in Canada. Bank of Canada Review, (Spring): 19-33.

12. Daneshfar, A. and S. Hashemiyeh. 2002. Earnings Persistence And Profit Sharing Adoption. University of New Haven. Working Paper.

13. Estreicher, S. 1994. Collective Bargaining or "Collective Begging"?: Reflections on Antistrike Breaker Legislation. Michigan Law Review, 93: 577-609.

14. Estrin, S. and N. Wilson. 1989. Profit Sharing, The Marginal/Cost of Labour And Employment Variability. Department of Economics, London School of Economics.

15. Fitzroy, F. R. and K. Kraft. 1987. Cooperation, Productivity, And Profit Sharing. Quarterly Journal of Economics, 102: 23-35.

16. Gregg, P. A. and S. J. Machin. 1988. Unions And The Incidence of Performance-Linked Pay Schemes in Britain. International Journal of Industrial Organization, 6: 91-107.

17. Hansen, F. 2000. An Update on International Labor Costs. Compensation \& Benefits Review, 32: 14-20.

18. Hogan, R. G. and S. J. Kerstein. 1999. Employer Retirement Obligations in a Changing World. Journal of Financial Service Professional, 53: 62-67.

19. Jensen, M. C. and K. J Murphy. 1990. Performance Pay And Top-Management Incentives. Journal of Political Economy, 98: 225-264.

20. Jones, D. C. and T. Kato. 1993. Employee Stock Ownership Plans And Productivity in Japanese Manufacturing Firms. British Journal of Industrial Relations, 31: 331-347.

21. Jones, D. C. and J. Pliskin. 1991. Unionization And The Incidence of Performance-Based Compensation: Evidence From Canada. Hamilton College (Department of Economics). Working Paper.

22. Kaufman, B. and D. Taras. 1999. Nonunion Employee Representation: Introduction. Journal of Labor Research, 20: 1-8.

23. Kaufman, B. E. and D. G. Taras. 1999. Nonunion Employee Representation: Introduction. Journal of Labor Research, 20: 1-9.

24. Kim, S. 1993. Profit Sharing And Profitability of Firms in The United States: A Simultaneous Equation Approach. UCLA (Graduate School of Management). Working Paper.

25. Kren, L. and J. L. Kerr. 1993. The Effect of Behavior Monitoring and Uncertainty on The Use of Performance-Contingent Compensation. Accounting and Business Research, 23: 159-168.

26. Kruse, D. L. 1991. Pension Substitutions in The 1980s: Why The Shift Toward Defined Contribution Plans?. National Bureau of Economic Research. Working Paper.

27. Kruse, D. L. 1993. Profit Sharing: Does it Make a Difference?. Michigan: W.E. Upjohn Institute of Employment Research.

28. Kruse, D. L. 1996. Why do Firms Adopt Profit Sharing And Employee Ownership Plans?. British Journal of Industrial Relations, 34: 515-539.

29. Lawler, E. 1992. A Skill-Based Approach to Human Resource Management. European Management Journal, 10: 383, 392.

30. LeRoy, M. H. 1996. Can Team Work? Implications of An Electromation And Dupont Compliance Analysis For The TEAM Act. The Notre Dame Law Review, 71: 215-216.

31. Levine, P. 1995. Policy Issues in The Operation of Currency Unions. The World Economy, 18: 507-509.

32. Long, R. J. 1989. Patterns of Workplace Innovations in Canada. Industrial Relations, 44: 805-826.

33. Long, R. J. 1994. Gain Sharing, Hierarchy And Managers. Are They Substitutes?. Proceeding of 1994 Annual Conference, Administrative Science Association of Canada, Organization Theory Division.

34. Long, R. J. 1997. Motives For Profit Sharing: A Study of Canadian Chief Executive Officers. Industrial Relations, 52: 712-733.

35. Majerus, R. E. 1984. Workers Have a Right to a Share of Profits. Harvard Business Review, 62: $42-50$. 
36. Metzger, B. L. 1978. Profit Sharing in 38 Large Companies: Piece of Action For 1000,000 Participants. Evanston, Illinois: Profit Sharing Research Foundation.

37. Miles, R. 1975. Theories of Management: Implications For Organizational Behaviour And Development. New York: Mcgraw-Hill.

38. Poole, M. 1989. The Origin of Economic Democracy: Profit-Sharing And Employee- Shareholding Schemes. London: Routledge.

39. Sorrentino, C. and J. Moy. 2002. US Labor Market Performance in International Perspective. Monthly Labor Review, 125: 15-35.

40. Sparks, C. and M. Greiner. 1997. US And Foreign Productivity And Unit Labor Costs. Monthly Labor Review, 120: 26-35.

41. Spencer, D. 1994. 1994 Survey Sources For U.S. And International Pay And Benefits. Employee Benefit Plan Review, 49: 53.

42. Stroh, L. K., J. M. Drett, J. P. Baumann and A. H. Reilly. 1996. Agency Theory And Variable Pay Compensation Strategies. Academy of Management Journal, 39, 751-768.

43. Tosi, H. L. and L. R. Gomez-Mejia. 1989. The Decoupling of CEO Pay And Performance: An Agency Theory Perspective. Administrative Science Quarterly, 34: 169-189.

44. Wagar, T. and R. J. Long. 1995. Profit Sharing in Canada: Incidence And Predictors. Proceeding of The 1995 Conference, Administrative Science Association of Canada Human Resources Division.

45. Walsh, J. P. and J. K. Seward. 1990. On The Efficiency of Internal And External Corporate Control Mechanism. Academy of Management Review, 15: 421-458.

46. Watts, R. L. and J. L. Zimmerman. 1986. Positive Accounting Theory. Englewood Cliffs: N. J., PrenticeHall.

47. Welbourne, T. M., D. Balkin and L. R. Gomez-Mejia. 1995. Gain Sharing and Mutual Monitoring: A Combined Agency- Organizational Justice Interpretation. Academy of Management Journal, 38: 881-899.

48. Whitmore, D. 1999. Productivity: The "In-Word" For The Millennium? Management Services, 43: 8-10.

49. Zingheim, P. K. and J. R. Schuster. 2000. Value Is The Goal. Workforce, 79: 56-62.

50. Zou, L. 1997. Incentive Roles of Fringe Benefits in Compensation Contracts. Bell Journal of Economics, 65: 181-199. 


\section{NOTES}

